\title{
Epigenetic immunomodulatory effect of eugenol and astaxanthin on doxorubicin cytotoxicity in hormonal positive breast Cancer cells
}

Mariam A. Fouad', Mohamed M. Sayed-Ahmed ${ }^{1}$, Etimad A. Huwait ${ }^{2}$, Hafez F. Hafez ${ }^{1}$ and Abdel-Moneim M. Osman ${ }^{1 *}$

\begin{abstract}
Background: Hormonal receptor positive (HR+) breast cancer is the most commonly diagnosed molecular subtype of breast cancer; which showed good response to doxorubicin (DOX)-based chemotherapy. Eugenol (EUG) and astaxanthin (AST) are natural compounds with proved epigenetic and immunomodulatory effects in several cancer cell lines. This study has been initiated to investigate the molecular mechanism (s) whereby EUG and AST could enhance DOX cytotoxicity in MCF7 cells.

Methods: Cytotoxic activity of DOX alone and combined with either $1 \mathrm{mM}$ EUG or $40 \mu \mathrm{M}$ AST was performed using sulphorhodamine-B assay in MCF7 cells. Global histones acetylation and some immunological markers were investigated using ELISA, western blotting and quantitative RT-PCR techniques. Functional assay of multidrug resistance was performed using rhodamine 123 and Hoechst 3342 dyes. Flow cytometry with annexin $V$ and propidium iodide were used to assess the change in cell cycle and apoptosis along with the expression of some differentiation, apoptosis and autophagy proteins.

Results: DOX alone resulted in concentration-dependent cytotoxicity with $I C_{50}$ of $0.5 \mu \mathrm{M}$. Both EUG and AST significantly increased DOX cytotoxicity which is manifested as a significant decrease in DOX IC 50 from $0.5 \mu \mathrm{M}$ to $0.088 \mu \mathrm{M}$ with EUG and to $0.06 \mu \mathrm{M}$ with AST. Combinations of DOX with $1 \mathrm{mM}$ EUG or $40 \mu \mathrm{M}$ AST significantly increased the level of histones acetylation and histone acetyl transferase expression, while reduced the expression of aromatase and epidermal growth factor receptor (EGFR) when compared with $0.25 \mu \mathrm{M}$ DOX alone. Also both combinations showed higher uptake of rhodamine but lower of Hoechst stains, along with increased the percentage of caspase 3, and decreased the expression of CK7 and LC3BI/II ratio. EUG combination induced IFY but reduced TNFa causing shifting of cells from G2/M to $S$ and G0/ G1 phases. Combination of DOX with EUG induced apoptosis through the higher BAX/ BCl2 ratio, while with AST was through the increase in caspase 8 expressions.
\end{abstract}

Conclusion: EUG and AST potentiated the anticancer activity of DOX through epigenetic histones acetylation along with the immunonomodulation of different apoptotic approaches in MCF7 cells.

Keywords: Eugenol, Astaxanthin, Doxorubicin, Breast Cancer cells

\footnotetext{
* Correspondence: moneimosman@hotmail.com

'Pharmacology and Experimental Oncology Unit, National Cancer Institute, Cairo University, Cairo 11796, Egypt

Full list of author information is available at the end of the article
} 


\section{Background}

According to the most recent Global Cancer Statistics issued in 2018, breast cancer is the most commonly diagnosed cancer among females and the leading cause of cancer death [1]. Hormonal receptor-positive $(\mathrm{HR}+)$ breast cancer is the most common molecular subtype of breast cancer and represents about $84 \%$ of breast cancer cases [2]. Breast cancer is a heterogenous disease, in which variant molecular features and therapeutic responses were noticed among patients [3]. Epigenetic modifications were amongst the potential players in hormone resistance. De novo and drug induced alterations in DNA methylation, in the promoter regions of genes, have an impact on the initiation and progression of breast cancer [4, 5]. Epigenomic approach through histones acetylation has become a crucial strategy in the way to solve the acquired resistance [6,7]. The dynamic reaction catalyzed by histone acetyltransferases (HATs) and histone deacetylases (HDACs) has a role in the stimulation or the suppression of tumor growth and progression [4]. Using a combination of HDAC inhibitor with chemotherapy; causes re-sensitization of resistant breast cancer cells to treatment [8,9]. In addition, the interaction of breast cancer cells with the surrounding microenvironment via interleukins and growth factors was found to have significant impact on the response to endocrine therapy [10]. Immunological regulatory protein such as tumour necrosis factor (TNF), interferon- $\gamma$ (IFN- $\gamma$ ) and forkhead box P3 (FOXP3) have shown direct/ indirect effects on cancer cell. They mediate the tumor-stromal cell interaction inducing range of matrix metalloproteinases, cytokines and chemokines to promote the tumor development and response to therapy [11, 12].

Doxorubicin (DOX) is an anthracycline antibiotic (Fig. 1a) with broad spectrum anti-tumour activity against many forms of human tumours. DOX induces its antitumor activity via both DNA-single and double strand breaks which is believed to be mediated by DNA intercalation, disruption of topoisomerase-II-mediated DNA repair and generation of free radicals and their damage to cellular membranes, DNA and protein [13]. It is one of the most commonly used chemotherapeutic agents in the treatment of $\mathrm{HR}+$ breast cancer patients with poor prognostic features [14]. Unfortunately, the optimal clinical usefulness of DOX is usually limited secondary to the development of multidrug resistance phenotype as a major limitation observed in $\mathrm{HR}+$ breast cancer treatment [15]. In an attempt to minimize the serious side effects of DOX and to increase its activity, variety of approaches has been investigated using safe and natural compounds [16-18].

Eugenol (EUG) and astaxanthin (AST) are wellknown phytochemical which have proven anticancer properties against breast cancer [19-21]. Eugenol (4-allyl (-2-mthoxyphenol, Fig. 1b) showed versatile pharmacological actions in different types of cancer [22]. It has genoprotective effects against oxidative and methylated DNA damage [23]. Also, it has dose-dependent suppressive and enhancing effects on the immune response invitro and in- vivo [24, 25].

Astaxanthin, a marine derived xanthophyll carotenoid (Fig. 1c), has shown to target epigenetic modifying enzymes such as DNA methyltransfersases (DNMTs) and HDACs [26, 27]. Several mechanisms have been proposed for AST induced immunological and anti- inflammatory effects including enhancing both cell-mediated and humoral immune responses. It improves IFN- $\gamma$ and IL-2 secretion, natural killer cell cytotoxic activity and reduces the intracellular oxidative stress [28, 29]. Accordingly, the current study has been initiated to investigate, on mechanism-based, whether the epigenetic and immunomodulatory effects of EUG and AST could enhance DOX cytotoxicity in $\mathrm{HR}+$ breast cancer cells (MCF7).

\section{Methods}

\section{Drugs and chemicals}

DOX, EUG an AST were obtained from Sigma Aldrich Chemical Co. (St. Louis, MO, USA). Each vial of DOX contains $10 \mathrm{mg}$ doxorubicin hydrochloride in powdered form which was dissolved in DMSO to yield $10 \mu \mathrm{M}$ then serially diluted in RPMI-1640 medium immediately before use. EUG was obtained in a vial containing 100\% pure essential oil. It was dissolved in DMSO and diluted

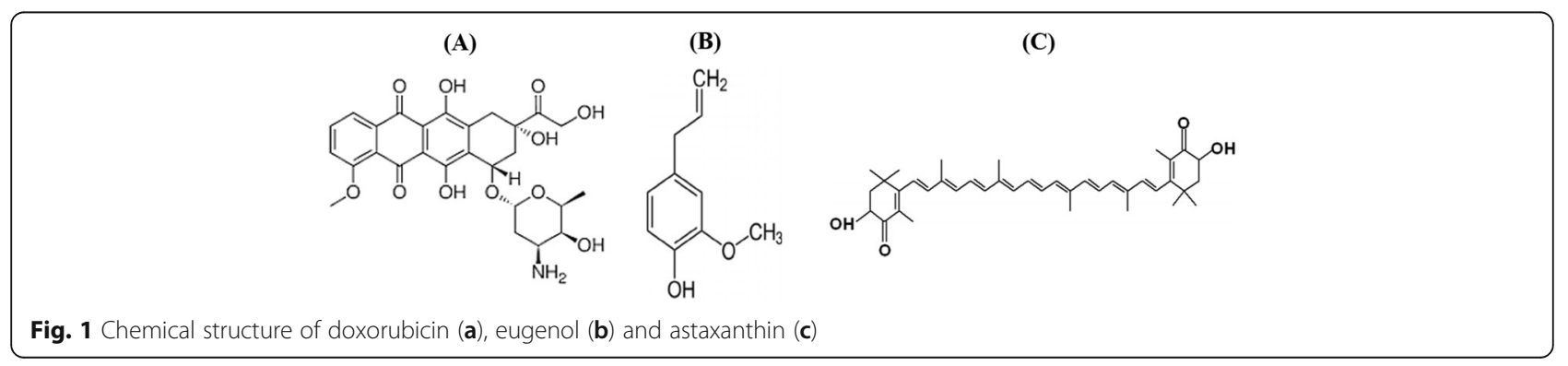


with RPMI-1640 supplemented medium immediately before use. AST was purchased as pink to very dark purple powder stored away from light and dissolved in DMSO to produce stock of $2000 \mu \mathrm{M}$. RPMI-1640 Medium, fetal bovine serum, dimethylsulfoxide (DMSO), sodium bicarbonate, Hoechst 3342 solution $1 \mathrm{mg} / \mathrm{ml}$, and rhodamine 123 were all purchased from Sigma Aldrich Chemical Co. (St. Louis, MO, USA). Trichloroacetic acid (TCA) and Triton X-100 were procured from MP Biochemical (Santa Ana, California, USA). All other chemicals and reagents were from standard analytical grade.

\section{Cells and cell culture}

Human breast cancer cell line (MCF7, ATCC HTB22 $^{\text {mat }}$ ) used in this study was obtained from the American Type Culture Collection (Manassas, USA). The adherent cells were grown as monolayer in RPMI- 1640 supplemented with $10 \%$ fetal bovine serum, $2 \mathrm{mM} \mathrm{L}$-glutamine, $1.5 \mathrm{~g} / \mathrm{l}$ sodium bicarbonate and $1 \%$ penicillin/streptomycin, and incubated at $37 \mathrm{C}$ in 5\% CO2 atmosphere.

\section{Methods}

\section{Assessment of cytotoxic activity}

Cytotoxicity was determined using sulforhodamine B (SRB) assay as previously described by Skehan et al. [30]. Briefly, exponentially growing cells were seeded in 96-well microtitre plates at an initial density of $5 \times 10^{3} /$ well. After $24 \mathrm{~h}$, cells were incubated with different concentration of EUG (0.125-4 mM), AST $(5-80 \mu \mathrm{M})$, DOX (0.0625$1 \mu \mathrm{M})$ alone. Increasing concentrations of DOX were combined with decreasing concentrations of EUG or AST for isobologram combination analysis and synergistic dose selection. Combination of DOX with $1 \mathrm{mM}$ EUG or $40 \mu \mathrm{M}$ AST were carried out for combination index and fraction affected analyses. For each concentration, three wells were used and incubation was continued for another $48 \mathrm{~h}$. Drug free wells were exposed to vehicles (DMSO 1\% $\mathrm{v} / \mathrm{v})$ and were used as control. Cells were incubated in a humidified, $5 \% \mathrm{CO} 2$ atmosphere at $37 \mathrm{C}$ for $48 \mathrm{~h}$. Cells were fixed with $10 \%$ trichloroacetic acid for $1 \mathrm{~h}$ at $4 \mathrm{C}$ and stained with $0.4 \%$ SRB for $30 \mathrm{~min}$. The wells were then washed four times with $1 \%$ acetic acid, air-dried and the dye was solubilized with $10 \mathrm{mM}$ Tris base ( $\mathrm{pH} 10.5)$. The optical density (O.D.) was measured spectrophotometrically at $570 \mathrm{~nm}$ with the microplate reader (Tecan Sunrise $^{\mathrm{Tw}}$, Ma" nnedorf, Switzerland). The experiment was repeated in three independent times. $\mathrm{IC}_{50}$ values (the concentration of DOX required to produce $50 \%$ inhibition of cell growth) were calculated using sigmoidal dose response curve-fitting models (Graphpad Prizm Software, version 5, GraphPad Software, Inc. Avenida de la Playa La Jolla, USA). Isobologram analysis and combination index calculation was done using CombuSyn software (ComboSyn, Inc., Paramus, NJ., USA).

\section{Cell cycle and apoptosis analysis with flow cytometry}

Control and treated MCF7 cell pellets were stained with DAPI/Triton X-100 staining solution for cell cycle analysis and with propidium iodide for apoptosis analysis [31]. A flow cytometer (Becton and Dickinson San Jose, CA., USA) equipped with electronic doubletdiscrimination capability was used to detect stained nuclei and emitted fluorescent light primarily at wavelengths between 580 and $650 \mathrm{~nm}$. The FACscan fluroscence 2 (FL2) detector equipped with a 585/42 band pass filter was used to analyze light emitted between 564 and $606 \mathrm{~nm}$.

\section{RNA extraction, CDNA synthesis and real time PCR}

Total RNA was extracted from control and treated cell pellets with total RNA purification kit (Direct-Zol RNA Kit, Zymo Research, Germany). cDNA synthesis was performed using Revert Aid First Strand cDNA synthesis kit (ThermoFisher, UK), in which $1 \mu \mathrm{l}$ reverse transcriptase enzyme was added to $10 \mu \mathrm{l}$ RNA sample in the presence of $2 \mu \mathrm{l}$ of RT buffer, $0.8 \mu \mathrm{l}$ dNTP mix, $2 \mu \mathrm{l}$ random primers, $1 \mu \mathrm{l}$ RNase inhibitor and $3.2 \mu \mathrm{l}$ nuclease-free water. The cycling conditions were $25^{\circ} \mathrm{C}$ for $10 \mathrm{~min}$, $37^{\circ} \mathrm{C}$ for $120 \mathrm{~min}$ and $85^{\circ} \mathrm{C}$ for $60 \mathrm{~min}$. Quantitative real time PCR was conducted by Applied Biosystems syber green PCR master mix (USA). $1 \mu \mathrm{l}$ of cDNA was added to $25 \mu$ master mixtures of CXR Reference Dye, forward and reverse primers and double distilled $\mathrm{H}_{2} \mathrm{O}$. Initial denaturation at $95^{\circ} \mathrm{C}$ for $10 \mathrm{~min}$, followed by 40 cycles of denaturing at $95^{\circ} \mathrm{C}$ for $15 \mathrm{~s}$, and annealing at $62^{\circ} \mathrm{C}$ for 1 min was performed for all analyses in triplicate on a 7500 Real-Time PCR System (Applied Biosystems, Foster City, CA, USA). The cycle threshold (Ct) was determined automatically. Three samples without a template were always included as a no template control. Reverse and forward sequences of primers genes encoding for mRNA transcript of TNF $\alpha$, IFN $\gamma$, FOXP3, BAX, BCl2 and caspase 8 genes were designed by NCBI- NIH tool and the sequences were summarized in Table 1. Fold

\begin{tabular}{|c|c|c|}
\hline Gene & Forward Primer & Reverse Primer \\
\hline$T N F a$ & CTGAACTTCGGGGTGATCG & GCTTGGTGGTTTGCTACGAC \\
\hline IFNy & ACTGTCGCCAGCAGCTAAAA & TATTGCAGGCAGGACAACCA \\
\hline FOXP3 & CCCAGGAAAGACAGCAACCTT & TTCTCACAACCAGGCCACTTG \\
\hline$B A X$ & GCCCTITTGCTTCAGGGTTT & TCCAATGTCCAGCCTITG \\
\hline$B C / 2$ & CGGAGGCTGGGATGCCTITG & TITGGGGCAGGCATGTTGAC \\
\hline caspase 8 & TTCTCCCTACAGGGTCATGC & GCAGGCTCAAGTCATCTTCC \\
\hline$\beta$ - actin & CCAGAGCAAGAGAGGTATCC & CTGTGGTGGTGAAGCTGTAG \\
\hline
\end{tabular}


change of genes expression $\left(2^{-\Delta \Delta C t}\right)$ was calculated after normalization to housekeeping gene ( $\beta$-actin) and genes expression in control samples.

\section{SDS-polyacrylamide gel electrophoresis and immunoblot analysis}

Control and treated cells were harvested, washed twice with ice-cold phosphate buffered saline, centifuged and pelleted at $1200 \mathrm{r} / \mathrm{min}$ for $5 \mathrm{~min}$. The cell pellets were then lysed in lysis buffer containing 150 $\mathrm{mM}$ sodium chloride, $10 \mathrm{mM}$ Tris, $0.2 \%$ Triton $\mathrm{X}$ 100, $0.3 \%$ NP-40, $0.2 \mathrm{mM}$ sodium vanadiumoxide and protease inhibitor cocktail, $\mathrm{pH}$ 7.7. The supernatants were collected after centrifugation at $14,000 \mathrm{r} / \mathrm{min}$ for $15 \mathrm{~min}$ at $4 \mathrm{C}$, and the protein content was determined by the Bradford method [32]. Aliquots of protein supernatants containing equal amounts of protein and sodium dodecyl sulphate (SDS)-reducing buffer were boiled for $5 \mathrm{~min}$, electrophoresed on SDSpolyacrylamide gels and transferred to polyvinylidene difluoride membranes. The membranes were blocked with $5 \%$ non-fat drymilk and probed with specific primary antibodies of monoclonal antihuman aromatase (Biospes, Aachen, Germany), EGFR (Sigma Aldrich, USA), CK7 (Bioss, Boston, USA) and LC3B (Invitrogen, USA) antibodies followed by incubation with peroxidase-conjugated secondary antibodies. The blots were developed with Amersham ECL Western Blotting Detection Reagents (GE Healthcare, Amersham Place, Little Chalfont, UK) according to themanufacturer's protocol. The blots were quantified by Scion image software (Scion Corporation, version 0.4.0.3, Maryland, USA) and protein loading was corrected for $\beta$-actin as loading control.

\section{Histones extraction and the determination of global H3 and $\mathrm{H} 4$ acetylation}

Cell pellets were suspended in triton extraction buffer (0.5\% Triton in phosphate buffered saline, $2 \mathrm{mM}$ phenylmethylsulfonyl fluoride and $0.02 \%$ NaN3), and lysed on ice for $10 \mathrm{~min}$ with gentle stirring. After centrifugation, cell lysate was transferred to a new vial and the residual cells were resuspended in the extraction buffer $(0.5 \mathrm{~N}$ $\mathrm{HCl}+10 \%$ glycerol) and incubated on ice for $30 \mathrm{~min}$. The supernatant fraction was taken to a new vial and 8 volumes of acetone was added and left at $-20^{\circ} \mathrm{C}$ overnight. The Protein concentration was quantified in the remaining dry pellet by Coomassie protein assay kit following Bradford method [32]. The EpiQuik ${ }^{\mathrm{Tm}}$ Total Histone $\mathrm{H} 3$ and $\mathrm{H} 4$ Acetylation Detection Fast Kits (Epigentek, Farmingdale, NY, USA) were used according to the manufacturer' protocol. The global content of acetylated histones in treated samples was calculated from the protein calibration curve in $\mathrm{ng} /$ total histones protein, and then the $\%$ of histones acetylation in was calculated normalized to the level of acetylated histones in untreated control.

\section{Enzyme-linked immunosorbent assay for caspase 3}

The concentration of executioner caspase 3 active subunit was measured in the lysate of MCF-7 cells using the Quantikine human active caspase-3 immunoassay kit (R\&D system, Minneapolis, MN, USA). The amount of caspase- 3 was calculated from a standard curve, and the results are presented as relative \% of active caspase- 3 to untreated control.

\section{Determination of the activity of multidrug resistance (MDR) via rhodamine-123 and Hoechst dyes}

Rhodamine-123 and Hoechst 3342 dyes are substrates for MDR genes and the proteins codified by these genes including $\mathrm{p}$-glycoprotein (P-gp), MDR associated protein, breast cancer resistant protein and lungresistant related protein [33]. Accumulation of Rhodamine-123 and Hoechst dyes in the cells is inversely related to MDR activity [34]. In brief, adherent control and treated cells were incubated with $5.25 \mu \mathrm{M}$ of Rhodamine 123 and $5 \mu \mathrm{g} / \mathrm{ml}$ of Hoechst 33342 dye for $30 \mathrm{~min}$ at $37 \mathrm{C}$ in a $5 \% \mathrm{CO} 2$ incubator. After incubation, cells were washed, scrapper collected, re-suspended and physically lysed in distilled water for immediate fluorescence analysis. Cellular uptake of Rhodamine 123 was detected at excitation $485 \mathrm{~nm}$ and emission $535 \mathrm{~nm}$, while cellular uptake of Hoechst 3342 was detected at excitation $360 \mathrm{~nm}$ and emission $450 \mathrm{~nm}$ using fluorescence spectroscopy (Kontron SFM25, Tresser Instruments, Rossdorf, Germany).

\section{Statistical analysis}

All data are expressed as mean \pm SD of three separate experiments, each performed in triplicates. Differences between groups were tested for statistical significance using one-way analysis of variance (ANOVA) followed by Dunnette for comparing all means with control in the SRB cytotoxicity study and Tukey-kramer for multiple comparison in rest of the experiments. A student t-test was used for comparison between the mean in DOX alone and the corresponding mean in DOX combined with either EUG or AST in SRB cytotoxicity study. Nonparametric ANOVA was carried out for comparison between three blots of Western blotting using the Kruskal-Willis test. The 0.05 level of probability was used as the criterion of significance using GraphPad InStat, version 4.0 (GraphPad, San Diego, California, USA). 


\section{Results}

Effect of EUG or AST on DOX cytotoxicity in MCF-7 cells

Figure 2 shows the effects of EUG (A) and AST (B) on the survival of MCF7 cells after $48 \mathrm{~h}$ incubation period. EUG and AST caused a concentration-dependent cell death. The IC50 recorded for EUG was $0.74 \mathrm{mM}$, and for AST was $33.8 \mu \mathrm{M}$. The concentration that produced significant decrease of survival in MCF7 for EUG and AST was the nearest concentration above the $\mathrm{IC}_{50}$ which found to be $1 \mathrm{mM}$ of EUG and $40 \mu \mathrm{M}$ of AST. Fig. 2c
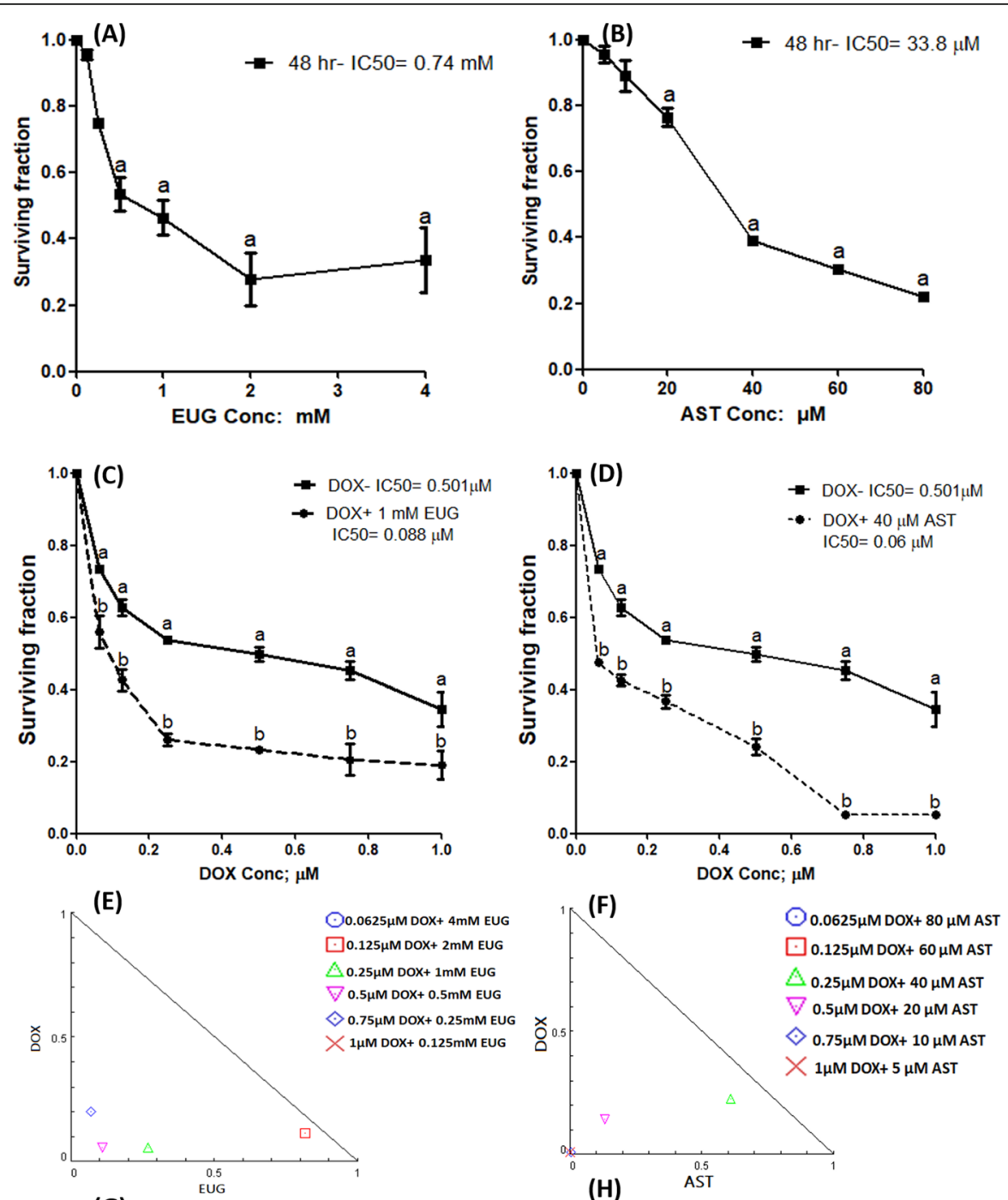

(G)
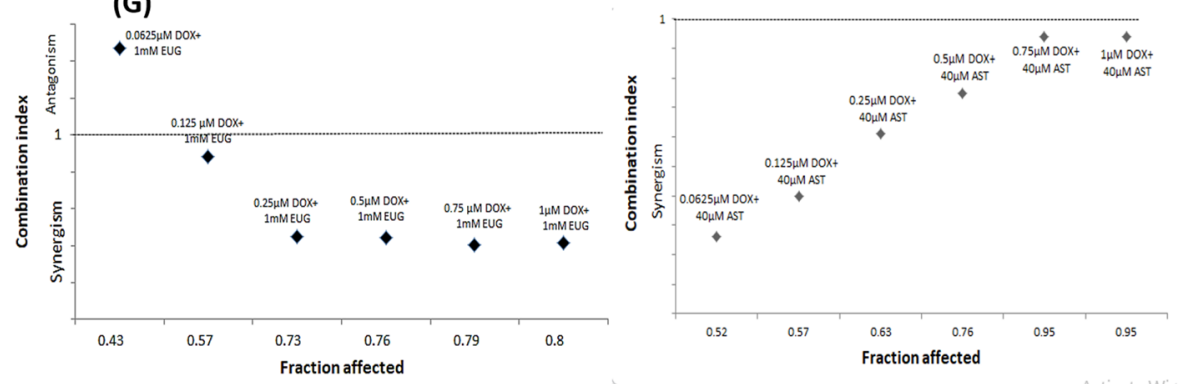

Fig. 2 Effect of EUG (a), AST (b), DOX plus EUG (c) and DOX plus AST (d) on survival of MCF7 cells. Normalized isobologram constructed for the combination of increasing concentrations of DOX with decreasing concentrations of EUG (e) and AST (f). The combination index produced from $1 \mathrm{mM}$ EUG combined with $0.25 \mu \mathrm{M}$ DOX ( $\mathbf{g})$ and $40 \mu \mathrm{M}$ AST combined with $0.25 \mu \mathrm{M}$ DOX (h). Data are expressed as mean \pm SD of three separate experiments, each performed in triplicates. ${ }^{a}$ indicates significant change from control at $P \leq 0.05$ using one-way ANOVA followed by Dunette as a post ANOVA test and ${ }^{\mathrm{b}}$ indicates significant from DOX alone at $\mathrm{P} \leq 0.05$ using student t-test. 
and d showed the effects of $1 \mathrm{mM}$ EUG (C) and $40 \mu \mathrm{M}$ AST (D) combined with various concentrations (0.0625$1 \mu \mathrm{M})$ of DOX for $48 \mathrm{~h}$ on the survival of MCF7 cells. DOX alone resulted in concentration-dependent cytotoxicity with $\mathrm{IC}_{50}$ of $0.5 \mu \mathrm{M}$. Both EUG and AST significantly increased DOX cytotoxicity manifested as a significant decrease in $\mathrm{DOX} \mathrm{IC}_{50}$ from $0.5 \mu \mathrm{M}$ to 0.088 with EUG (C) and to $0.06 \mu \mathrm{M}$ with AST (D).

Normalized isobologram was constructed for various descending concentrations of EUG or AST with various ascending concentrations of DOX as shown in (Fig. 2e and f). EUG showed synergistic cytotoxic effect with DOX in combinations: $0.125 \mu \mathrm{M}$ DOX +2 mM EUG, $0.25 \mu \mathrm{M}$ DOX+ $1 \mathrm{mM}$ EUG, $0.5 \mu \mathrm{M}$ DOX+ $0.5 \mathrm{mM}$ EUG and $0.75 \mu \mathrm{M}$ DOX $+0.25 \mathrm{mM}$ EUG (Fig. 2e), while AST showed synergistic cytotoxic effect with DOX in combinations: $0.25 \mu \mathrm{M}$ DOX+ $40 \mu \mathrm{M}$ AST and $0.5 \mu \mathrm{M}$ DOX $+20 \mu \mathrm{M}$ AST (Fig. 2f). The combination index-fraction affected graph was drawn and presented in (Fig. $2 \mathrm{~g}$ and h) for EUG and AST, respectively. The combination of $0.25 \mu \mathrm{M}$ DOX $+1 \mathrm{mM}$ EUG caused reduction in the cell growth of MCF7 by a fraction of 0.73 , and a synergistic combination index of 0.44 (Fig. $2 \mathrm{~g}$ ). The combination of $0.25 \mu \mathrm{M}$ DOX $+40 \mu \mathrm{M}$ AST caused reduction in the cell growth of MCF7 by a fraction of 0.61 , and a synergistic combination index of 0.63 (Fig. 2h). EUG and AST showed synergistic cytotoxic effects upon combination with DOX against the growth of MCF-7 cells.

\section{The effect of EUG and AST on the level of histones acetylation in DOX treated MCF7 cells}

Significant increase in $\mathrm{H} 3$ acetylation was shown only with EUG treatment compared with control (Fig. 3a). The combination of DOX with EUG caused a significant increase in both $\mathrm{H} 3$ and $\mathrm{H} 4$ histones acetylation, while with AST it caused only a significant increase in $\mathrm{H} 3$ histone acetylation, compared with DOX alone (Fig. 3a). Significant increase in $\mathrm{H} 4$ histone acetylation was demonstrated in both EUG and AST combination compared with their corresponding single treatment of each (Fig. 3a). HAT protein expression was significantly increased in DOX, EUG and AST treated cells compared with control (Fig. $3 \mathrm{~b}$ and c). Also, a significant overexpression of HAT was demonstrated in cells treated with DOX combined with EUG and AST compared with DOX, EUG and AST each alone (Fig 3 and c). EUG and AST showed an epigenetic potential through increasing global histones acetylation and HAT protein expression.
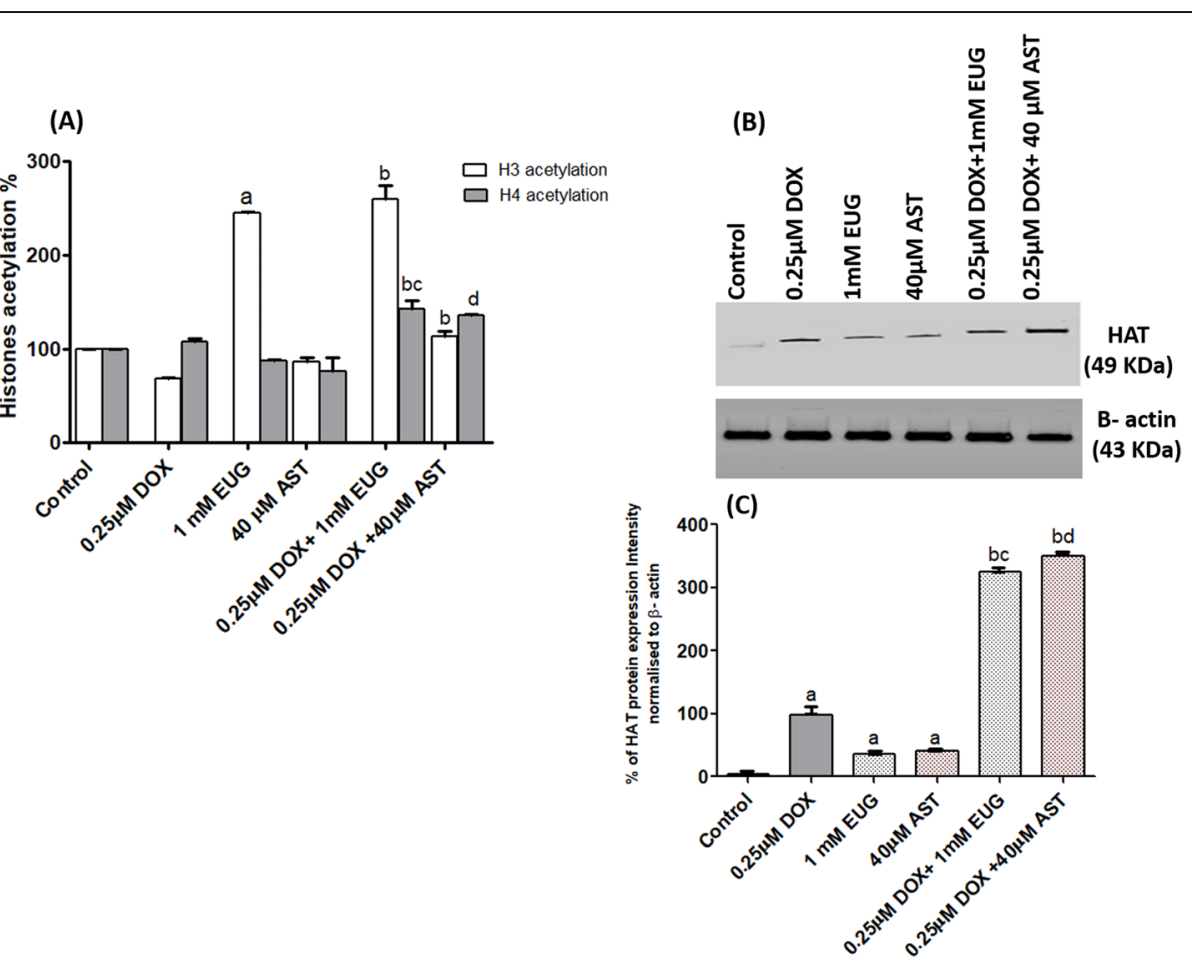

Fig. 3 Effect of DOX, EUG, AST and their combination on Histones ( $\mathrm{H} 3$ and H4) acetylation \% (a), HAT protein expression (b), and \% of HAT protein intensity normalised to $\beta$-actin (c). Data are expressed as mean \pm SD of three separate experiments, each performed in triplicates. ${ }^{a, b, c}$ and ${ }^{d}$ indicate significant from control, DOX, EUG and AST, respectively at $\mathrm{P} \leq 0.05$ using one-way ANOVA followed by Tukey-Kramer as a post ANOVA test. 
Immunological modulation of EUG and AST to DOX activity on FOXP3, IFN $\gamma$, TNFa, aromatase and EGFR expression in MCF7 cells

In (Fig. 4a), single treatment with DOX and EUG caused a significant decrease in FOXP3 and TNF $\alpha$, but increased mRNA expression of IFN $\gamma$ compared with control. Single treatment with AST caused significant mRNA overexpression of FOXP3, IFN $\gamma$ and TNF $\alpha$ compared with control. EUG combination caused a significant increase in IFN $\gamma$ but it decreased TNF $\alpha$ compared with DOX. AST plus DOX combination caused a significant decrease in FOXP3 expression compared with AST alone and also caused a significant decrease in IFNy expression compared with single DOX and AST. The expression of TNF $\alpha$ in AST plus DOX was higher than in DOX but lower than in AST alone. In (Fig. $4 \mathrm{~b}$ and c), single treatment with DOX, EUG and AST caused significant decrease in aromatase and EGFR protein expression compared with control. DOX combinations with EUG and AST caused further decrease in aromatase and EGFR protein expression compared with single treatment with DOX, EUG and AST. EUG and AST decreased protein expression of aromatase and EGFR.

\section{EUG and AST modulated the multidrug resistance of MCF7 cells to DOX}

DOX treated cells had significant lower uptake of rhodamine 123 (Fig. 5a), but higher uptake of hoechst3342 (Fig. 5b), compared with control. EUG and AST treated cells had significant higher uptake of rhodamine 123 (Fig. 5a), and hoechst3342 (Fig. 5b), compared with control. The combination of DOX with EUG resulted in significant higher uptake of rhodamine123 compared with single treatment with DOX and EUG (Fig. 5a). The combination of DOX with AST resulted in significant higher uptake of rhodamine123 compared with single treatment with DOX but lower uptake of rhodamine123 compared with single treatment with AST (Fig. 5a). Cells treated with EUG and AST combination showed lower Hoechst 3342 uptake than cells treated with DOX, but higher Hoechst 3342 uptake than cells treated with single EUG or AST (Fig. 5b). EUG and AST decreased MDR activity.

\section{Cell cycle and apoptosis analysis with flow cytometry} Increased accumulation of cells in G0/G1 was observed after treatment with DOX (2.01\%) and AST (5.87\%) each alone, whereas EUG alone showed accumulation (1.64\%)

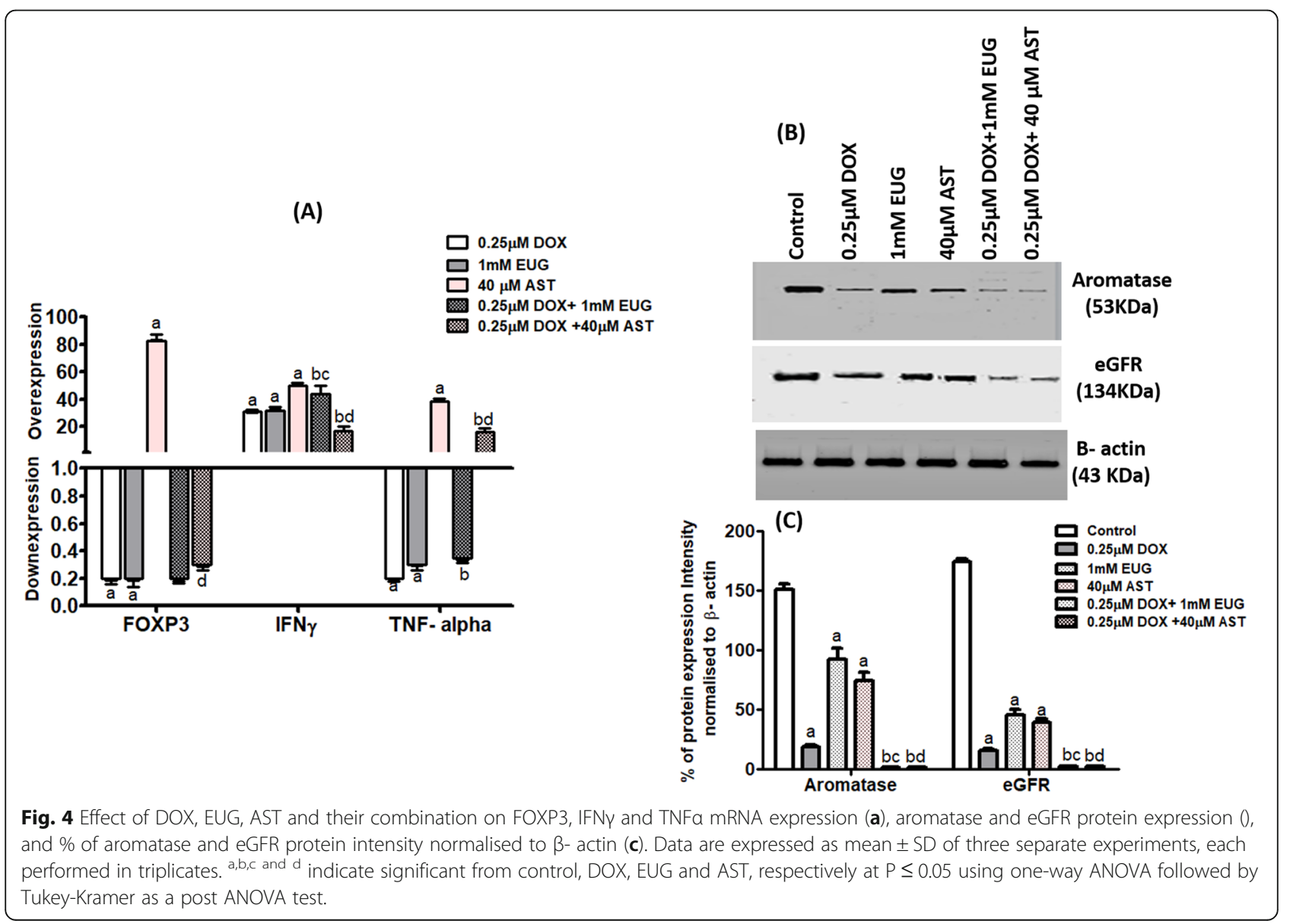



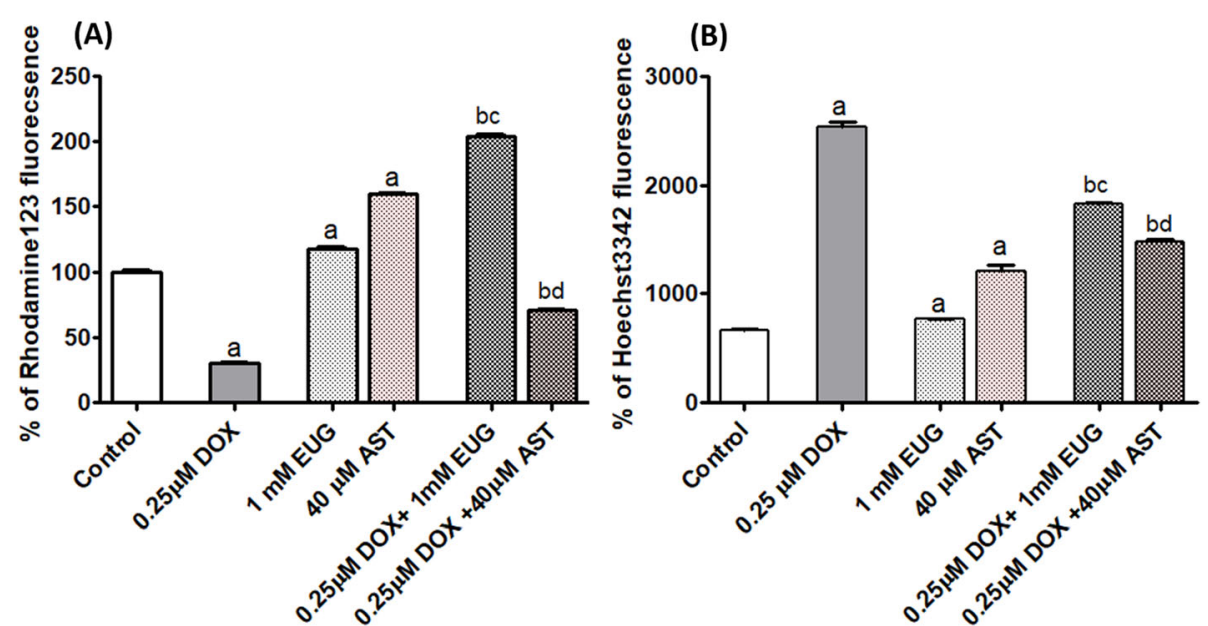

Fig. 5 Effect of DOX, EUG, AST and their combination on \% of rhodamine123 uptake (a) and \% of hoechst3342 uptake (b). Data are expressed as mean \pm SD of three separate experiments, each performed in triplicates. ${ }^{a, b}, \mathrm{c}$ and d indicate significant from control, DOX, EUG and AST, respectively at $\mathrm{P} \leq 0.05$ using one-way ANOVA followed by Tukey-Kramer as a post ANOVA test.

similar to control (1.56\%). Fascinatingly, the combination of DOX with EUG resulted in five folds increase in the percentage of cells in G0/G1 (10.99\%) compared with cells treated with DOX alone (2.01\%). Although AST alone showed the highest accumulation of cells in the G0/G1
(5.87\%), it has no effect on DOX- induced accumulation of cells in G0/G1 (Fig. 6a). EUG and AST combination caused early apoptosis to $1.25 \%$ of cells compared with $0.87 \%$ of cells treated with DOX alone (Fig. 7c). EUG and AST caused early apoptosis to DOX treated MCF7 cells.
(A)

\begin{tabular}{|l|c|c|c|}
\hline & G0/G1 & S & G2/M \\
\hline Control & 1.56 & 0.79 & 97.65 \\
\hline $\mathbf{0 . 2 5} \mu \mathrm{M}$ DOX & 2.01 & 3.23 & 94.76 \\
\hline $\mathbf{1 m M}$ EUG & 1.64 & 0.86 & 97.50 \\
\hline $\mathbf{4 0} \boldsymbol{\mu M}$ AST & 5.87 & 4.00 & 90.13 \\
\hline $\mathbf{0 . 2 5} \boldsymbol{M M}$ DOX+1mM EUG & 10.99 & 12.72 & 76.29 \\
\hline $\mathbf{0 . 2 5} \boldsymbol{\mu M}$ DOX+40 $\boldsymbol{M M}$ AST & $\mathbf{2 . 8 9}$ & 2.80 & $\mathbf{9 4 . 3 1}$ \\
\hline
\end{tabular}

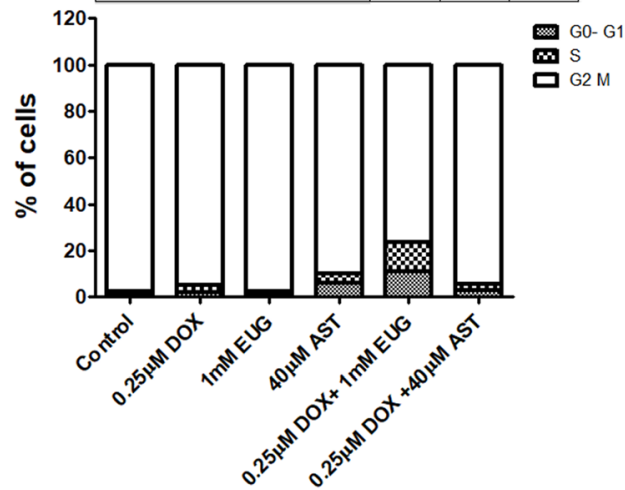

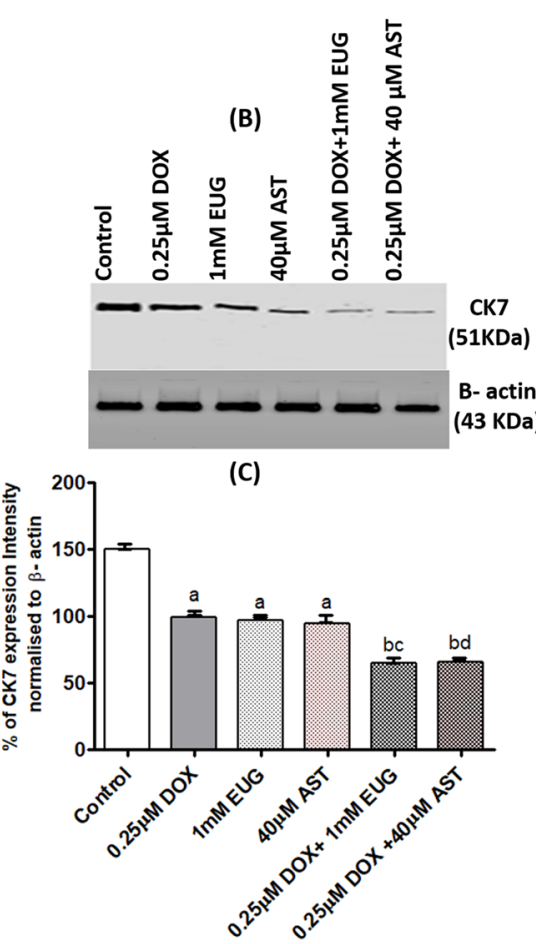

Fig. 6 Effect of DOX, EUG, AST and their combination on \% of cells at the phases of cell cycle (a), CK7 protein expression (b), and \% of CK7 protein intensity normalised to $\beta$-actin (c). Data are expressed as mean \pm SD of three separate experiments, each performed in triplicates. ${ }^{a}, b, c$ and ${ }^{d}$ indicate significant from control, DOX, EUG and AST, respectively at $P \leq 0.05$ using one-way ANOVA followed by Tukey-Kramer as a post ANOVA test. 


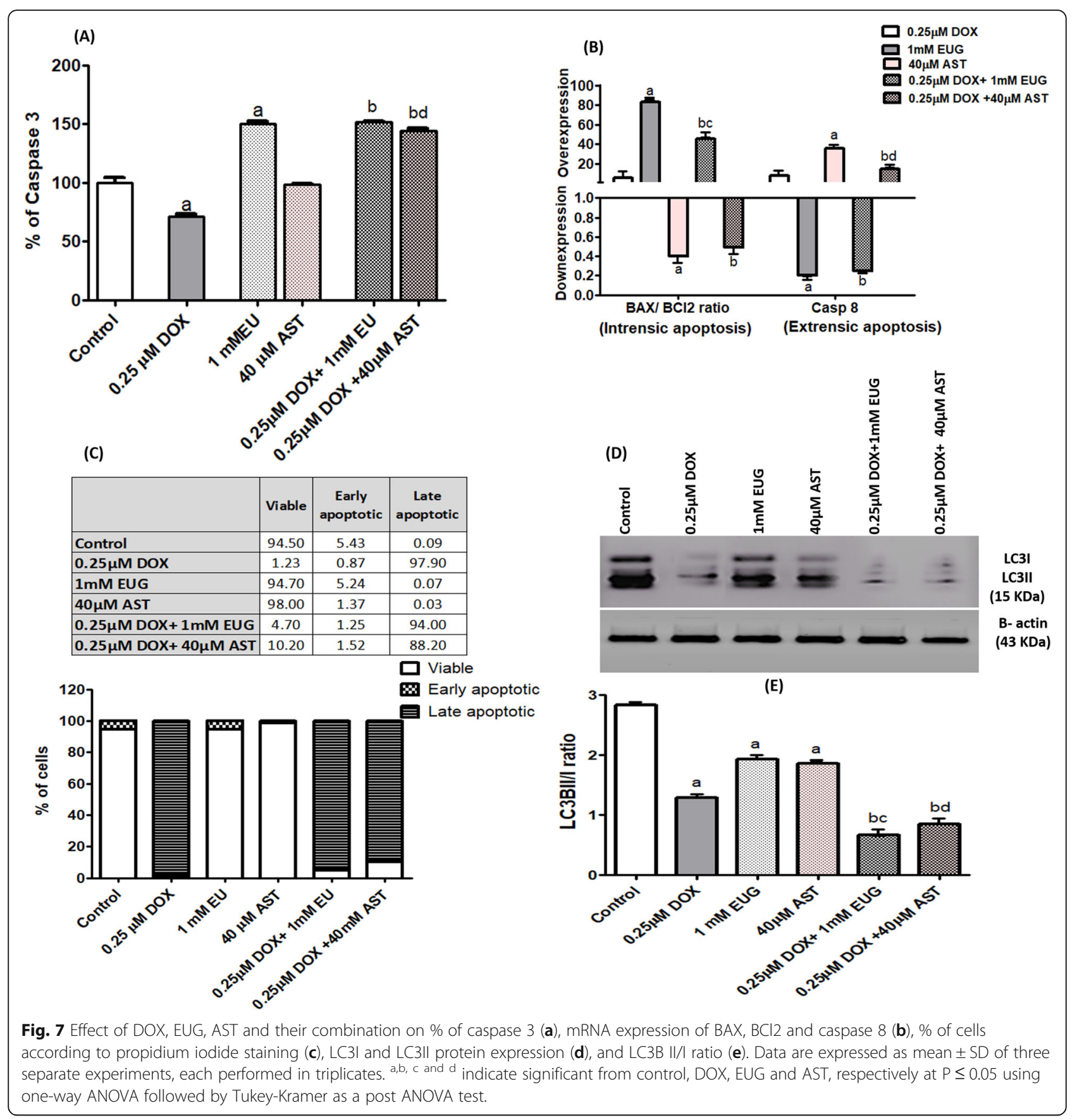

Both EUG and AST combinations inhibited the expression of CK7

Protein expression of luminal differentiation marker (cytokeratin 7: CK7) was shown to be significantly reduced in MCF7 cells treated with single DOX, EUG and AST compared with control, and further reduction was observed when DOX combined with EUG and AST compared with single DOX, EUG and AST (Fig. 6b). EUG and AST decreased CK7 protein expression.
EUG induced intrinsic apoptosis through $\mathrm{BAX} / \mathrm{BCl} 2$ while AST induced extrinsic apoptosis through caspase 8 and both activated caspase 3 but reduced LC3B expression The percentage of active caspase 3 subunit was shown to be significantly reduced in DOX treated cells, while significantly induced in EUG treated cells, compared with control. Combination of EUG with DOX significantly induced capase 3\% compared with DOX alone. While combination of AST with DOX significantly induced capase 3\% compared with DOX and AST alone 
(Fig. 7a). Single treatment with EUG showed significant overexpression of $\mathrm{BAX} / \mathrm{BCl} 2$ ratio, but downexpression of caspase 8, compared with control. On the contrary, AST showed significant downexpression of $\mathrm{BAX} / \mathrm{BCl} 2$ ratio, but overexpression of caspase 8 , compared with control. Cells treated with EUG combination revealed significant higher level of $\mathrm{BAX} / \mathrm{BCl} 2$ ratio but lower level caspase 8 compared with cell treated with DOX alone. Cells treated with EUG combination revealed significant lower level of $\mathrm{BAX} / \mathrm{BCl} 2$ ratio when compared with cells treated with EUG alone. When AST combination compared with DOX, significant lower level of $\mathrm{BAX} / \mathrm{BCl} 2$ ratio but significant higher level of caspase 8 was revealed. The level of caspase 8 mRNA expression in cells treated with AST combination was lower than in cells treated with AST alone (Fig. 7b). The protein expression of autophagic marker (LC3BII/I ratio) was shown to be significantly reduced in MCF7 cells treated with single DOX, EUG and AST compared with control, and further reduction was observed when EUG and AST combinations compared with single DOX, EUG and AST (Fig. 7d). EUG induced apoptosis by increasing $\mathrm{BAX} / \mathrm{BCl} 2$ ratio, while AST induced apoptosis via increasing caspase-8 expression.

\section{Discussion}

DOX is among the most commonly used anticancer drugs with broad spectrum antitumor activity against several human tumours including breast cancer. Unfortunately, the optimal clinical benefits of DOX are limited secondary to its detrimental cardiomyopathy and the development of MDR [35, 36]. Earlier studies have demonstrated that EUG attenuated DOX-induced genotoxicity and cardiotoxicity $[16,17]$. Similarly, AST treatment significantly protected against DOX-induced oxidative and inflammatory insults and downregulated the overactive apoptotic machineries [18]. Therefore, the current study extended such beneficial effects of EUG and AST by testing their combination with DOX in MCF7 to investigate, on mechanism-based, whether EUG and AST could enhance the sensitivity of HR+ MCF7 cells to DOX, and if so, whether these effects are linked to MDR-P-gp pathway and/or the non-MDR-epigenetic immunomodulation.

Data presented in the current study showed that EUG and AST induced remarkable enhancement in DOX cytotoxicity in MCF-7 cells manifested as a significant 82 and $88 \%$ decrease in the $\mathrm{IC}_{50}$, respectively as compared to DOX alone (Fig. 2). Our results confirmed earlier study which has reported that EUG induced cytotoxic activity against different molecular subtypes of breast cancer cells and induced apoptosis in a p53independent manner [19]. Using MCF7 cells, Vidhya and Devaraj [37] reported that EUG treatment caused concentration and time-dependent inhibition of growth and proliferation of the cells and increased the percentage of apoptotic cells and DNA fragmentation through depleting the level of intracellular glutathione and increasing the level of lipid peroxidation.

The current results showed that addition of EUG to DOX-treated cells resulted in shifting MCF-7 cells toward the $\mathrm{S}$ and G0/ G1 phases and induced the intrinsic apoptosis through the higher $\mathrm{BAX}$ to $\mathrm{BCl} 2$ ratio (Fig. $7 \mathrm{~b}$ ). In concordance, DOX induced mitochondrial-dependent apoptosis by down-regulation of Bcl-xL and upregulation of Bax and caspase-9 expressions in MCF7 cells [38]. In addition, Júnior et al. [39] pointed that EUG induced apoptosis in cancer cells through promoting the production of reactive oxygen species and reducing the mitochondria potential through the upregulation of Bax expression causing the abrogation of cells from the G2/M of phase of cell-cycle. Moreover, the chemo-sensitivity of MCF-7 cells to EUG was found to be mainly mediated through the distortion of mitochondrial membrane integrity with the consequent release of cytochrome-c and lactate dehydrogenase into culture media at EUG concentration more than its effective concentration 50 [20]. Therefore, one can anticipate a synergistic harmony between DOX and EUG in the molecular insights leading to apoptosis. On the other hand, our results revealed that DOX combination with AST induced apoptosis through overexpression of caspase 8, the key enzyme of the extrinsic apoptosis [40], and there was insignificant change in the distribution of cells through the phases of cell cycle. Under similar experimental condition, Sharifi et al. reported that DOX induced non-significant change in the level of caspase 8 after $24 \mathrm{~h}$ incubation, but significantly increased its level after 48 and $72 \mathrm{~h}$ of incubation [38]. Different modes of AST driving apoptosis when combined with DOX were recently reported $[41,42]$. It has been reported that, the pro-oxidant property of AST was the main force for selective apoptosis MCF7 cells in which growth inhibition was increased in a synergistic pattern rather than normal breast epithelial cells (MCF-10A) [41]. In vivo study concluded that AST caused up-regulation of tumor suppressor p53 gene, potentiating DOX cytotoxicity and apoptosis against mammary tumor cells but accumulating them in the G2/M phase of the cell cycle [42].

Earlier studies confirmed that DOX-treated MCF-7 cell developed varying degrees of resistance depending on the concentration of DOX used [43] and that DOX is a selective P-gp substrate, and induced expression of MDR in tumor cells [44]. Therefore, to test EUG and AST sensitization of MCF7 to DOX treatment, the current study followed two approaches; one through the direct measurement of MDR-Pgp post-translational activity, and the other is non-MDR mediated through the 
measurement of CK7, LC3B, immunological and epigenetic markers. In this study, the sensitization of MCF7 cells to DOX treatment was investigated by the functional assay of MDR depending on the intracellular accumulation of Rhodamine 123 and Hoechst dyes [45, 46]. Our results showed that treatment with DOX alone caused reduced intracellular Rhodamine 123 accumulation but induced that of Hoeacsht 3342, indicating the basal sensitive nature of our MCF7 cells (Fig. 5b). Combined use of EUG or AST with DOX induced higher uptake of Rhodamine123, but lower of Hoechst 3342 than DOX alone, indicating the switch on induction of the Pgp activity upon combination treatment. In DOX resistant breast cancer cells, the pumping of DOX out of cells was shown to be dependent on ATP avaliability [47]. The possibility of alterations in P-gp activity might be explained by changes in P-gp protein levels in DOX treated cells [33]. Moreover, P-gp activity may be modulated by cellular components such as membrane proteins, membrane-anchoring proteins or membrane-lipid composition [48]. Alterations of mitochondrial membrane potential and intracellular ATP level by EUG [20, 49] and AST were reported [50, 51] and explained the difference in the intracellular accumulation of DOX in combination than single agent. By reversing DOX resistance, DOX accumulate in MCF7 cells by endocytosis bypassing the effect of P-gp mediated efflux [52].

In our study, the combination of DOX with both EUG and AST significantly decreased CK7 expression. It is well known that cells with positive expression of CK7 exhibited resistance to DOX treatment [53, 54]. The immunomodulation potency of EUG and AST on the differentiation of mesenchymal stem cells which affect therapy applications was reported $[55,56]$. For further elucidation of the non-MDR directed EUG and AST sensitization to DOX anticancer activity in MCF7 cells, we investigated the effect of DOX alone and combined with EUG or AST on EGFR and aromatase expression. Our results showed that EUG and AST alone induced mild anti-EGFR effect. However, after combined treatment with DOX, EUG or AST, caused marked reduction in EGFR and aromatase proteins expression. Our results are consistent with previous studies which reported that increased the number of EGFR in tumor was associated with DOX resistance [57], and that combination of DOX with anti-EGFR therapy enhanced DOX effects against EGFR overexpressed tumor xenografts [58]. The ability of EUG to block HER2/PI3K-AKT signalling in breast precancerous lesions was reported [59]. In cervical cancer cells, AST reduced the expression of EGFR and interfere with EGF binding, thereby inducing apoptosis [60]. Aromatase and estrogen receptor $\alpha(E R \alpha)$ are two key proteins which are responsible for the proliferation of MCF7 cells [61]. Our results showed a significant inhibition in aromatase protein expression after treatment with DOX. Pritchard et al. showed that DOX induced changes on estrogen signaling relevant to its therapeutic efficacy [14]. However, the presence of physiological estrogen levels will reverse DOX cytotoxic effect in breast cancer cells [14]. The anti-oxidant and anti-inflammatory activities of EUG and AST were suggested to contribute in their anti-aromatase effects. The idea was exported from the well- known aromatase inhibitor (exemestane) which showed non-estrogenic chemopreventive activity through its anti-inflammatory and reactive oxygen species scavenging properties [62]. Red clover flowers (from which EUG was extracted) were found to inhibit aromatase at low concentrations, while they had estrogenic activity at high concentrations [63]. Moreover, we suggest that the known antihyperlipidemic effect of AST [64] may also contribute in its aromatase inhibitory activity [65]. Especially there is a classical correlation between ER-positive breast cancers and adipose tissue expression of aromatase, which is considered a local source of estrogens [66].

Autophagy is the main reason for acquired resistance phenotype in ER+ breast cancer, and its molecular target LC3B is found to be highly expressed in the breast cancer tissues [67]. Data presented in the current study showed that the expression of LC3BI and II was vanished in cells treated with DOX combined with EUG or AST as compared to each alone (Fig. 7d). In colorectal cancer cells, EUG was identified as pro-autophagic compound [68], where the active fraction of clove (oleanonic acid and eugenol) increased LC3B I and II and Beclin-1 protein expression. AST modulates the signaling pathways that regulate autophagy [69], either by stimulation as shown in an experimental model of non-alcoholic fatty liver disease [70], or by inhibition as shown in the pancreas by inhibiting the JAK/STAT3 pathway [71]. Also the anti-oxidant and reactive oxygen scavengining activities of EUG [72] and AST [73] during DOX treatment may explain for the classical autophagic inhibition usually observed in that context with other anti-oxidant compounds [74].

Under our experimental condition; the epigenetic potential of EUG and AST was evaluated, and it was found that EUG alone and the combinations of DOX with $1 \mathrm{mM}$ EUG or $40 \mu \mathrm{M}$ AST significantly induced the level of global histones acetylation along with increasing the protein expression of histone acetyl transferase (Figs. 3a, b and c). This histone deacetylase inhibition activity observed with EUG illustrates its proautophagic effect and intrinsic apoptotic cell death. On the same way, most of histone deacetylase inhibitors can induce mitochondria-mediated apoptosis and provoke autophagy-induced caspaseindependent cell death $[75,76]$. The inhibitory effect 
of AST on histone deacetylase 9 expressions was observed [77]. Combination of DOX with histone deacetylase inhibitors promoted DOX-induced apoptosis through a mechanism that involved induction of tumor suppressor gene PTEN which is the major negative regulator of the PI3K/Akt cellular survival pathway [78]. According to that, the proven induction of $\mathrm{H} 3$ and $\mathrm{H} 4$ histone acetylation by EUG and AST was suggested to contribute in the DOX synergistic cell death observed in this study.

In the present study, exposure of MCF7 cells to either DOX or EUG alone significantly decreased expression of FOXP3 and TNFa and increased expression of IFNy, while AST caused overexpression of the three genes (Fig. 4a). DOX combined with EUG significantly increased IFN $\gamma$ expression and decreased TNFa expression when compared with DOX alone. The vice versa was observed when AST combined with DOX where a significant reduction in IFN $\gamma$ expression accompanied with TNF $\alpha$ overexpression in comparison with DOX alone. Both EUG and AST combinations showed no change in FOXP3 expression compared with single treatment with DOX. Moreover, DOX induced a remarkable increase in Foxp3 protein in MCF7 cells that was associated with the phosphorylation of p53 [79]. Recent study suggested that the antitumor effect of EUG was secondary to its regulatory action on the production of inflammatory mediators from macrophages Barboza et al. [25]. EUG reduced TNF- $\alpha$ and IL-1 $\beta$ as well as the NF- $\kappa \mathrm{B}, \mathrm{ERK} 1 / 2$, and p38 MAPK signaling pathways [80]. EUG exhibited synergistic effect when combined with gemcitabine by downregulating the expression of Bcl-2, COX-2 and IL1- $\beta$ [81]. It has been also reported that EUG induced downregulation of TNF- $\alpha$ in LPS-activated macrophages, which was associated with antigenotoxic activity when DNA damage was induced with DOX [16]. Additionally, it was reported that EUG synergistically increased cisplatin cytotoxicity against triple negative breast cancer through the inhibition of NF- $\kappa B$ signalling pathway, p50 and p65 subunits phosphorylation, and IL-6 and IL-8 downregulation [82]. In tumor environment, it has been reported that AST decreased the amount of inflammatory markers such as TNF- $\alpha$, IL-6, and IFN $\gamma$ via NFk-B inhibition [83]. In mouse breast cancer model, AST treatment caused higher levels of apoptotic cancer cells and [84], promoted early check and elimination of cells undergoing malignant transformation by activating immune surveillance [85] and prevented cancer cell growth in cells by boosting immune detection [86]. In sum, this study added to the previously identified benefits of EUG [17] and AST [87]. Their antioxidant and cardioprotective abilities against DOX toxicity have been exceeded to their post-translational modification ability through histones acetylation and immune regulation, which resulted in a significant synergism to DOX- cytotoxic effect on HR+ breast cancer cells (MCF7).

\section{Conclusions}

In conclusion, EUG and AST enhanced the cytotoxic activity of DOX through two different apoptotic approaches, mainly through the non-MDR pathway of histones acetylation and immunonomodulation in hormone receptor positive breast cancer cells. EUG and AST significantly synergize DOX cytotoxicity in $\mathrm{HR}+$ breast cancer cells. Combined use of EUG or AST with DOX significantly increased histones acetylation, Rhodamine123 uptake and caspase-3\%, and decreased protein expression of aromatase, EGFR, CK7 and LC3B. DOX combined with EUG significantly increased IFN $\gamma$ and decreased TNF $\alpha$ but vice versa was observed when AST combined with DOX where a significant reduction in IFN $\gamma$ expression accompanied with TNF $\alpha$ overexpression was shown in comparison with DOX alone. Both EUG and AST have nonsignificant effect on FOXP3 mRNA expression. EUG combination caused shifting of cells from $\mathrm{G} 2 / \mathrm{M}$ to $\mathrm{S}$ and G0/ G1 phases, whereas AST combination caused non-significant change. EUG combination induced apoptosis through increasing $\mathrm{BAX} / \mathrm{BCl} 2$ ratio, while AST combination was through increasing caspase- 8 expression.

Worth mentioning is that, the produced synergistic cytotoxicity of EUG and AST combined with DOX in MCF7 cells as a model of luminal A breast cancer subtype is likely could be reproduced in the other breast cancer molecular subtypes including luminal $\mathrm{B}$, triple negative and Her2-enriched. Therefore, our results warrant detailed mechanistic studies to confirm the chemosensitizing effects of EUG and AST to minimize the therapeutic dose of DOX with the consequent decrease in its organ toxicity.

\begin{abstract}
Abbreviations
DOX: Doxurobicin; EUG: Eugenol; AST: Astaxanthin; HR + : Hormonal receptor positive; EGFR: Epidermal growth factor receptor; HAT: Acetyltransferase; HDAC: Histone deacetylase; TNF: Tumour necrosis factor; IFN- $\gamma$ : Interferon- $\gamma$; FOXP3: Forkhead box P3
\end{abstract}

\section{Acknowledgements \\ Authors are grateful to Dr. Mohamed M. Hafez Prof. of Virology \& Immunology for facilitating the use of real time- PCR.}

Authors' contributions

MAF and HFH designed and performed the experimental work and analysed the data. MMS shared in analysis and interpretation of the data. EAH shared in analysis and interpretation of the data and AMO suggested the research problem and designed the experimental work. All authors contributed in writing and revising of the manuscript and approved it. 


\section{Funding}

This research is supported from the annual research fund by National Cancer Institute, Cairo University.

\section{Availability of data and materials}

All data analyzed in this study is available from the corresponding author on reasonable request.

\section{Ethics approval and consent to participate}

This article does not contain any studies with human or animal subjects performed by the authors.

\section{Consent for publication}

Not applicable.

\section{Competing interests}

The authors declared that have no competing interest.

\section{Author details}

${ }^{1}$ Pharmacology and Experimental Oncology Unit, National Cancer Institute, Cairo University, Cairo 11796, Egypt. ²Department of Biochemistry, Faculty of Sciences, King Abdulaziz University, Experimental Biochemistry Unit, King Fahad Medical Research Centre, Jeddah, Saudi Arabia.

Received: 1 July 2020 Accepted: 5 January 2021

Published online: 28 January 2021

\section{References}

1. Bray F, Ferlay J, Soerjomataram I, Siegel RL, Torre LA, Jemal A. Global cancer statistics 2018: GLOBOCAN estimates of incidence and mortality worldwide for 36 cancers in 185 countries. CA Cancer J Clin. 2018;68(6):394-424. https://doi.org/10.3322/caac.21492.

2. American Cancer Society. Breast Cancer Facts \& Figures 2019-2020. Atlanta: American Cancer society, Inc:; 2019.

3. Turashvili G, Brogi E. Tumor Heterogeneity in Breast Cancer. Front Med (Lausanne). 2017;4:227. https://doi.org/10.3389/fmed.2017.00227.

4. Abdel-Hafiz HA, Horwitz KB. Role of epigenetic modifications in luminal breast cancer. Epigenomics. 2015;7(5):847-62. https://doi.org/10.2217/epi.15. 10

5. Wang Q, Gun M, Hong XY. Induced Tamoxifen resistance is mediated by increased methylation of E-cadherin in estrogen receptor-expressing breast Cancer cells. Sci Rep. 2019;9(1):14140. https://doi.org/10.1038/s41598-01950749-1.

6. Connolly R, Stearns V. Epigenetics as a therapeutic target in breast cancer. J Mammary Gland Biol Neoplasia. 2012;17(3-4):191-204. https://doi.org/10. 1007/s10911-012-9263-3.

7. Feng Q, Zhang Z, Shea MJ, et al. An epigenomic approach to therapy for tamoxifen-resistant breast cancer. Cell Res. 2014;24(7):809-19. https://doi. org/10.1038/cr.2014.71

8. Sandhu R, Rivenbark AG, Coleman WB. Enhancement of chemotherapeutic efficacy in hypermethylator breast cancer cells through targeted and pharmacologic inhibition of DNMT3b. Breast Cancer Res Treat. 2012;131(2): 385-99. https://doi.org/10.1007/s10549-011-1409-2.

9. Li J, Hao D, Wang L, et al. Epigenetic targeting drugs potentiate chemotherapeutic effects in solid tumor therapy. Sci Rep. 2017:7:4035. https://doi.org/10.1038/s41598-017-04406-0.

10. Segovia-Mendoza M, Morales-Montor J. Immune tumor microenvironment in breast cancer and the participation of estrogen and its receptors in cancer physiopathology. Front Immunol. 2019;10:348. https://doi.org/10. 3389/fimmu.2019.00348.

11. Esquivel-Velázquez M, Ostoa-Saloma P, Palacios-Arreola MI, Nava-Castro KE, Castro Jl, Morales-Montor J. The role of cytokines in breast cancer development and progression. J Interf Cytokine Res. 2015;35(1):1-16. https:// doi.org/10.1089/jir.2014.0026

12. Soysal SD, Tzankov A, Muenst SE. Role of the tumor microenvironment in breast Cancer. Pathobiology. 2015;82(3-4):142-52. https://doi.org/10.1159/ 000430499.

13. Gewirtz DA. A critical evaluation of the mechanisms of action proposed for the antitumor effects of the anthracycline antibiotics adriamycin and daunorubicin. Biochem Pharmacol. 1999:57(7):727-41. https://doi.org/10. 1016/s0006-2952(98)00307-4.
14. Pritchard JE, Dillon PM, Conaway MR, Silva CM, Parsons SJ. A mechanistic study of the effect of doxorubicin/adriamycin on the estrogen response in a breast cancer model. Oncology. 2012;83(6):305-20. https://doi.org/10.1159/ 000341394.

15. Ponnusamy L, Mahalingaiah PKS, Singh KP. Treatment schedule and estrogen receptor-status influence acquisition of doxorubicin resistance in breast cancer cells. Eur J Pharm Sci. 2017;104:424-33. https://doi.org/10. 1016/j.ejps.2017.04.020

16. de Paula Porto M, Da Silva GN, Luperini BCO, et al. Citral and eugenol modulate DNA damage and proinflammatory mediator genes in murine peritoneal macrophages. Mol Biol Rep. 2014;41(11): 7043-51.

17. Fouad AA, Yacoubi MT. Mechanisms underlying the protective effect of eugenol in rats with acute doxorubicin cardiotoxicity. Arch Pharm Res. 2011; 34(5):821-8. https://doi.org/10.1007/s12272-011-0516-2.

18. El-Agamy SE, Abdel-Aziz AK, Wahdan S, Esmat A, Azab SS. Astaxanthin ameliorates doxorubicin-induced cognitive impairment (Chemobrain) in experimental rat model: impact on oxidative, inflammatory, and apoptotic machineries. Mol Neurobiol. 2018;55(7):5727-40. https://doi.org/10.1007/ s12035-017-0797-7.

19. Al-Sharif I, Remmal A, Aboussekhra A. Eugenol triggers apoptosis in breast cancer cells through E2F1/survivin down-regulation. BMC Cancer. 2013;13: 600. https://doi.org/10.1186/1471-2407-13-600.

20. Al Wafai R, El-Rabih W, Katerji M, et al. Chemosensitivity of MCF-7 cells to eugenol: release of cytochrome-c and lactate dehydrogenase. Sci Rep. 2017; 7:43730. https://doi.org/10.1038/srep43730.

21. McCall B, McPartland CK, Moore R, Frank-Kamenetskii A, Booth BW. Effects of Astaxanthin on the proliferation and migration of breast Cancer cells in vitro. Antioxidants (Basel). 2018;7(10):135. https://doi.org/10.3390/ antiox7100135.

22. Pramod K, Ansari SH, Ali J. Eugenol: a natural compound with versatile pharmacological actions. Nat Prod Commun. 2010. https://doi.org/10.1177/ $1934578 \times 1000501236$

23. Thapa D, Richardson AJ, Zweifel B, Wallace RJ, Gratz SW. Genoprotective effects of essential oil compounds against oxidative and methylated DNA damage in human Colon Cancer cells. J Food Sci. 2019:84(7):1979-85. https://doi.org/10.1111/1750-3841.14665.

24. Rodrigues TG, Fernandes A Jr, Sousa JP, Bastos JK, Sforcin JM. In vitro and in vivo effects of clove on pro-inflammatory cytokines production by macrophages. Nat Prod Res. 2009;23(4):319-26. https://doi.org/10.1080/ 14786410802242679

25. Barboza JN, Bezerra Filho C DSM, Silva RO, JVR M, de Sousa DP. An Overview on the Anti-inflammatory Potential and Antioxidant Profile of Eugenol. Oxidative Med Cell Longev. 2018;2018:3957262. https://doi.org/10. $1155 / 2018 / 3957262$

26. Li R, Wu H, Zhuo WW, et al. Astaxanthin normalizes epigenetic modifications of bovine somatic cell cloned embryos and decreases the generation of lipid peroxidation. Reprod Domest Anim. 2015;50(5):793-9. https://doi.org/10.1111/rda.12589.

27. Yang Y, Fuentes F, Shu L, et al. Epigenetic CpG methylation of the promoter and reactivation of the expression of GSTP1 by Astaxanthin in human prostate LNCaP cells. AAPS J. 2017;19(2):421-30. https://doi.org/10.1208/ s12248-016-0016-X.

28. Park JS, Chyun JH, Kim YK, Line LL, Chew BP. Astaxanthin decreased oxidative stress and inflammation and enhanced immune response in humans. Nutr Metab (Lond). 2010;7:18. https://doi.org/10.1186/1743-7075-7-18.

29. Lin KH, Lin KC, Lu WJ, Thomas PA, Jayakumar T, Sheu JR. Astaxanthin, a carotenoid, stimulates immune responses by enhancing IFN- $\gamma$ and IL-2 secretion in primary cultured lymphocytes in vitro and ex vivo. Int J Mol Sci. 2015;17(1):44. https://doi.org/10.3390/ijms17010044.

30. Skehan P, Storeng R, Scudiero D, et al. New colorimetric cytotoxicity assay for anticancer-drug screening. J Natl Cancer Inst. 1990:82(13):1107-12. https://doi.org/10.1093/jnci/82.13.1107.

31. Pozarowski P, Darzynkiewicz Z. Analysis of cell cycle by flow cytometry. Methods Mol Biol. 2004;281:301-11. https://doi.org/10.1385/1-59259-811-0:301.

32. Bradford MM. A rapid and sensitive method for the quantitation of microgram quantities of protein utilizing the principle of protein-dye binding, j. Anal Biochem. 1976;72:248-54. https://doi.org/10.1016/00032697(76)90527-3.11.

33. Tang F, Ouyang H, Yang JZ, Borchardt RT. Bidirectional transport of rhodamine 123 and Hoechst 33342, fluorescence probes of the binding 
sites on P-glycoprotein, across MDCK-MDR1 cell monolayers. J Pharm Sci. 2004:93(5):1185-94. https://doi.org/10.1002/jps.20046.

34. Sayed-Ahmed MM. Multi drug resistance to cancer chemotherapy: genes involved and blockers. Saudi Pharm J. 2007;15:161-75.

35. Sayed-Ahmed MM, Al-Shabanah OA, Hafez MM, Aleisa AM, Al-Rejaie SS. Inhibition of gene expression of heart fatty acid binding protein and organic cation/carnitine transporter in doxorubicin cardiomyopathic rat model. Eur J Pharmacol. 2010;640(1-3):143-9.

36. Christowitz C, Davis T, Isaacs A, et al. Mechanisms of doxorubicin-induced drug resistance and drug resistant tumour growth in a murine breast tumour model. BMC Cancer. 2019;19:757. https://doi.org/10.1186/s12885019-5939-z.

37. Vidhya N, Devaraj SN. Induction of apoptosis by eugenol in human breast cancer cells. Indian J Exp Biol. 2011;49(11):871-8.

38. Sharifi S, Barar J, Hejazi MS, Samadi N. Doxorubicin Changes Bax /Bcl-xL Ratio, Caspase-8 and 9 in Breast Cancer Cells. Adv Pharm Bull. 2015;5(3):3519. https://doi.org/10.15171/apb.2015.049.

39. Júnior PL, Câmara DA, Costa AS, et al. Apoptotic effect of eugenol envolves G2/M phase abrogation accompanied by mitochondrial damage and clastogenic effect on cancer cell in vitro. Phytomedicine. 2016;23(7):725-35. https://doi.org/10.1016/j.phymed.2016.03.014.

40. Kominami K, Nakabayashi J, Nagai T, et al. The molecular mechanism of apoptosis upon caspase-8 activation: quantitative experimental validation of a mathematical model. Biochim Biophys Acta. 2012;1823(10):1825-40. https://doi.org/10.1016/j.bbamcr.2012.07.003.

41. Vijay K, Sowmya PR, Arathi BP, et al. Low-dose doxorubicin with carotenoids selectively alters redox status and upregulates oxidative stress-mediated apoptosis in breast cancer cells. Food Chem Toxicol. 2018;118:675-90. https://doi.org/10.1016/j.fct.2018.06.027.

42. AlQahtani AA, Osman AM, Al-Kreathy HM, Al-harthy SE, Al-malky HS, AL Nasser MS, Kamel FO, Alaama MN, Damanhouri ZA. Chemosensitizing effects of marine astaxanthin on the anti-cancer activity of doxorubicin in tumor bearing mice. Int J Cancer Res. 2019;15:1-8.

43. Trebunova M, Laputkova G, Slaba E, Lacjakova K, Verebova A. Effects of docetaxel, doxorubicin and cyclophosphamide on human breast cancer cell line MCF-7. Anticancer Res. 2012;32(7):2849-54.

44. Gustafson DL, Long ME. Alterations in P-glycoprotein expression in mouse tissues by doxorubicin: implications for pharmacokinetics in multiple dosing regimens. Chem Biol Interact. 2001 Oct 25;138(1):43-57.

45. Lahmy S, Viallet $P$, Salmon JM. Is reduced accumulation of Hoechst 33342 in multidrug resistant cells related to P-glycoprotein activity? Cytometry. 1995; 19(2):126-33. https://doi.org/10.1002/cyto.990190207.

46. van der Sandt IC, Blom-Roosemalen MC, de Boer AG, Breimer DD Specificity of doxorubicin versus rhodamine-123 in assessing Pglycoprotein functionality in the LLC-PK1, LLC-PK1:MDR1 and Caco-2 cell lines. Eur J Pharm Sci. 2000;11(3):207-14. https://doi.org/10.1016/ s0928-0987(00)00097-x.

47. Dartier J, Lemaitre E, Chourpa I, et al. ATP-dependent activity and mitochondrial localization of drug efflux pumps in doxorubicin-resistant breast cancer cells. Biochim Biophys Acta Gen Subj. 2017;1861(5 Pt A):107584. https://doi.org/10.1016/j.bbagen.2017.02.019.

48. Ponce de León V, Barrera-Rodríguez R. Changes in P-glycoprotein activity are mediated by the growth of a tumour cell line as multicellular spheroids. Cancer Cell Int. 2005;5(1):20. Published 2005 Jul 7. https://doi.org/10.1186/ 1475-2867-5-20

49. Yi JL, Shi S, Shen YL, et al. Myricetin and methyl eugenol combination enhances the anticancer activity, cell cycle arrest and apoptosis induction of cis-platin against HeLa cervical cancer cell lines. Int J Clin Exp Pathol. 2015; 8(2):1116-27.

50. Lu YP, Liu SY, Sun H, Wu XM, Li JJ, Zhu L. Neuroprotective effect of astaxanthin on $\mathrm{H}(2) \mathrm{O}(2)$-induced neurotoxicity in vitro and on focal cerebral ischemia in vivo. Brain Res. 2010;1360:40-8. https://doi.org/10.1016/j.brainres.2010.09.016.

51. Kim SH, Lim JW, Kim H. Astaxanthin inhibits mitochondrial dysfunction and Interleukin-8 expression in Helicobacter pylori-infected gastric epithelial cells. Nutrients. 2018;10(9):1320. https://doi.org/10.3390/nu10091320.

52. Zhou M, Li L, Li L, et al. Overcoming chemotherapy resistance vid simultaneous drug-efflux circumvention and mitochondrial targeting. Acta Pharm Sin B. 2019;9(3):615-25. https://doi.org/10.1016/j.apsb.2018.11.005.

53. Anderson JM, Heindl LM, Bauman PA, Ludi CW, Dalton WS, Cress AE. Cytokeratin expression results in a drug-resistant phenotype to six different chemotherapeutic agents. Clin Cancer Res. 1996;2(1):97-105.
54. Hsiao YL, Hsieh TZ, Liou CJ, et al. Characterization of protein marker expression, tumorigenicity, and doxorubicin chemoresistance in two new canine mammary tumor cell lines. BMC Vet Res. 2014;10:229. https:/doi.org/ 10.1186/s12917-014-0229-0.

55. Yazdani M, BidmeshkipourA., \& SisakhtnezhadS. Evaluating the effect of Eugenol on the expression of genes involved in the Immunomodulatoty potency of mouse Mesenchymal stem cells in vitro. J Cell Mol Res. 2018; 10(1):1-10. https://doi.org/10.22067/jcmr.v10i1.70380.

56. Wang $M$, Zhang J, Song $X$, et al. Astaxanthin ameliorates lung fibrosis in vivo and in vitro by preventing transdifferentiation, inhibiting proliferation, and promoting apoptosis of activated cells. Food Chem Toxicol. 2013;56:450-8. https://doi.org/10.1016/j.fct.2013.03.004.

57. Kwok TT, Sutherland RM. Epidermal growth factor reduces resistance to doxorubicin. Int J Cancer. 1991;49(1):73-6. https://doi.org/10.1002/ijc. 2910490114.

58. Baselga J, Norton L, Masui $H$, et al. Antitumor effects of doxorubicin in combination with anti-epidermal growth factor receptor monoclonal antibodies. J Natl Cancer Inst. 1993;85(16):1327-33. https://doi.org/10.1093/ jnci/85.16.1327.

59. Ma M, Ma Y, Zhang GJ, et al. Eugenol alleviated breast precancerous lesions through HER2/PI3K-AKT pathway-induced cell apoptosis and S-phase arrest. Oncotarget. 2017;8(34):56296-310. https://doi.org/10.18632/oncotarget.17626.

60. Muto Y, Fujii J, Shidoji Y, et al. Growth retardation in human cervical dysplasia-derived cell lines by beta-carotene through down-regulation of epidermal growth factor receptor. Am J Clin Nutr. 1995;62:1535S-40S.

61. Chan HJ, Petrossian K, Chen S. Structural and functional characterization of aromatase, estrogen receptor, and their genes in endocrine-responsive and -resistant breast cancer cells. J Steroid Biochem Mol Biol. 2016;161:73-83. https://doi.org/10.1016/j.jsbmb.2015.07.018.

62. Liu H, Talalay P. Relevance of anti-inflammatory and antioxidant activities of exemestane and synergism with sulforaphane for disease prevention. Proc Natl Acad Sci U S A. 2013;110(47):19065-70. https://doi.org/10.1073/pnas. 1318247110.

63. Almstrup K, Fernández MF, Petersen JH, Olea N, Skakkebaek NE, Leffers H. Dual effects of phytoestrogens result in $\mathrm{U}$-shaped dose-response curves. Environ Health Perspect. 2002;110(8):743-8. https://doi.org/10.1289/ehp. 02110743

64. Choi HD, Youn YK, Shin WG. Positive effects of astaxanthin on lipid profiles and oxidative stress in overweight subjects. Plant Foods Hum Nutr. 2011; 66(4):363-9. https://doi.org/10.1007/s11130-011-0258-9.

65. Baek AE, Nelson ER. The contribution of cholesterol and its metabolites to the pathophysiology of breast Cancer. Horm Cancer. 2016;7(4):219-28. https://doi.org/10.1007/s12672-016-0262-5.

66. Wang $X$, Simpson ER, Brown KA. Aromatase overexpression in dysfunctional adipose tissue links obesity to postmenopausal breast cancer. J Steroid Biochem Mol Biol. 2015;153:35-44 [PubMed: 26209254].

67. Felzen V, Hiebel C, Koziollek-Drechsler I, et al. Estrogen receptor a regulates non-canonical autophagy that provides stress resistance to neuroblastoma and breast cancer cells and involves BAG3 function. Cell Death Dis. 2015;6: e1812. https://doi.org/10.1038/cddis.2015.181.

68. Liu M, Zhao G, Zhang D, An W, Lai H, Li X, Lin X. Active fraction of clove induces apoptosis via PI3K/Akt/mTOR-mediated autophagy in human colorectal cancer HCT-116 cells. Int J Oncol. 2018:53:1363-73. https://doi. org/10.3892/ijo.2018.4465.

69. Kim SH, Kim H. Astaxanthin Modulation of Signaling Pathways That Regulate Autophagy. Mar Drugs. 2019;17(10):546. Published 2019 Sep 23. https://doi.org/10.3390/md17100546.

70. Jia Y, Wu C, Kim J, Kim B, Lee SJ. Astaxanthin reduces hepatic lipid accumulations in high-fat-fed C57BL/6J mice via activation of peroxisome proliferator-activated receptor (PPAR) alpha and inhibition of PPAR gamma and Akt. J Nutr Biochem. 2016;28:9-18. https://doi.org/10.1016/j.jnutbio. 2015.09.015.

71. Zhang H, Yang W, Li Y, Hu L, Dai Y, Chen J, Xu S, Xu X, Jiang H. Astaxanthin ameliorates cerulein-induced acute pancreatitis in mice. Int Immunopharmacol. 2018;56:18-28.

72. Gülçin I. Antioxidant activity of eugenol: a structure-activity relationship study. J Med Food. 2011;14(9):975-85. https://doi.org/10.1089/jmf.2010.0197.

73. Sztretye M, Dienes B, Gönczi M, Czirják T, Csernoch L, Dux L, Szentesi P, Keller-Pintér A. Astaxanthin: A Potential Mitochondrial-Targeted Antioxidant Treatment in Diseases and with Aging. Oxidative Medicine and Cellular Longevity, 2019; 2019. 
74. Underwood BR, Imarisio S, Fleming A, et al. Antioxidants can inhibit basal autophagy and enhance neurodegeneration in models of polyglutamine disease. Hum Mol Genet. 2010;19(17):3413-29. https://doi.org/10.1093/hmg/ ddq253.

75. Liu YL, Yang PM, Shun CT, Wu MS, Weng JR, Chen CC. Autophagy potentiates the anti-cancer effects of the histone deacetylase inhibitors in hepatocellular carcinoma. Autophagy. 2010;6(8):1057-65.

76. Mrakovcic M, Fröhlich LF. Regulation of HDAC inhibitor-triggered autophagy. SF Onco Cancer Res J. 2017;1:2-4.

77. Yang $Y$, Bae M, Park YK, et al. Histone deacetylase 9 plays a role in the antifibrogenic effect of astaxanthin in hepatic stellate cells. J Nutr Biochem. 2017;40:172-7. https://doi.org/10.1016/j.jnutbio.2016.11.003.

78. Pan L, Lu J, Wang $X$, et al. Histone deacetylase inhibitor trichostatin a potentiates doxorubicin-induced apoptosis by up-regulating PTEN expression. Cancer. 2007:109(8):1676-88. https://doi.org/10.1002/cncr.22585.

79. Jung DJ, Jin DH, Hong SW, et al. Foxp3 expression in p53-dependent DNA damage responses. J Biol Chem. 2010;285(11):7995-8002. https://doi.org/10. 1074/jbc.M109.047985.

80. Yeh $\mathrm{L}, \mathrm{Hsu} \mathrm{JH}$, Hong YS, et al. Eugenolol and glycerylisoeugenol suppress LPS-induced iNOS expression by downregulating NF-KB AND AP-1 through inhibition of MAPKS and AKT/KBa signaling pathways in macrophages. Int J Immunopathol Pharmacol. 2011;24(2):345-56.

81. Hussain K, Brahmbhatt A, Priyani M, Ahmed TA. Rizvi, and C. Sharma. Eugenol enhances the chemotherapeutic potential of gemcitabine and induces anticarcinogenic and anti-inflammatory activity in human cervical cancer cells. Cancer Biother Radiopharm. 2011;26(5):519-27.

82. Islam SS, Al-Sharif I, Sultan A, Al-Mazrou A, Remmal A, Aboussekhra A. Eugenol potentiates cisplatin anticancer activity through inhibition of ALDH-positive breast oxidative medicine and cellular longevity cancer stem cells and the NF-kB signaling pathway. Mol Carcinog. 2018;57(3):333-46.

83. Priyadarshini L, Aggarwal A. Astaxanthin inhibits cytokines production and inflammatory gene expression by suppressing IkappaB kinase-dependent nuclear factor kappaB activation in pre and postpartum Murrah buffaloes during different seasons. Vet World. 2018;11:782-8.

84. Nakao R, Nelson OL, Park JS, Mathison BD, Thompson PA, Chew BP. Effect of dietary astaxanthin at different stages of mammary tumor initiation in BALB/c mice. Anticancer Res. 2010;30(6):2171-5.

85. Yuan J-P, Peng J, Yin K, Wang J-H. Potential health-promoting effects of astaxanthin: a high-value carotenoid mostly from microalgae. Mol Nutr Food Res. 2011;55(1):150-65.

86. Kidd P. Astaxanthin, cell membrane nutrient with diverse clinical benefits and anti-aging potential. Altern Med Rev. 2011;16(4):355-64.

87. AlQahtani A, Osman A-M, Damanhouri Z, Al-Kreathy H, Al-Malky H, Ramadan W, Alharthi S, Kamel F. Cardioprotective effect of marine Astaxanthin on doxorubicin-induced Cardiotoxicity in Normal rats. J Pharm Res Int. 2019; 27(3):1-11. https://doi.org/10.9734/jpri/2019/v27i330170.

\section{Publisher's Note}

Springer Nature remains neutral with regard to jurisdictional claims in published maps and institutional affiliations.

\section{Ready to submit your research? Choose BMC and benefit from}

- fast, convenient online submission

- thorough peer review by experienced researchers in your field

- rapid publication on acceptance

- support for research data, including large and complex data types

- gold Open Access which fosters wider collaboration and increased citations

- maximum visibility for your research: over $100 \mathrm{M}$ website views per year

At $\mathrm{BMC}$, research is always in progress.

Learn more biomedcentral.com/submissions 